This is the accepted version of a forthcoming article that will be published by Sage in Southeast Asia Research: http://journals.sagepub.com/loi/sera Copyright: Konstantinos Retsikas. Reprinted with permission of Sage.

Accepted version downloaded from SOAS Research Online: http://eprints.soas.ac.uk/24263/

\title{
Introduction:
}

\section{Value Transfers in South East Asia}

\author{
Konstantinos Retsikas
}

SOAS University of London

\begin{abstract}
The special volume sets out to explore the complexities arising from contemporary intersections of religion and the economy as the later apply to public projects of transferring value to the poor for the purpose of alleviating their suffering, and improving their condition. It provides evidence of the new significance that religious interventions in the field of poverty alleviation are assuming in that part of the world in the era of neoliberal reform, with its case studies drawing upon ethnographic materials from Vietnam, Cambodia and Thailand in the north, to Malaysia and Indonesia in the south.
\end{abstract}

Keywords: religion, economy, poverty, development, Southeast Asia

Author details: Konstantinos Retsikas, Department of Anthropology, SOAS University of London, Thornhaugh Street, Russell Square, London WC1H 0XG, United Kingdom. Email: kr1@soas.ac.uk 
As in other parts of the world, public concerns over poverty as a social problem and the poor as a potential unruly section of the population have a long history in Southeast Asia. This concern is closely associated with a view propagated by several world religions - inclusive of Buddhism, Christianity and Islam - that one's worldly fortune and moral make-up mutually indicate one another, to the extent that one's low socio-economic position a is the result of one's lack of strength of morality and faith, and vice versa. The relation between religion and the economy thus conceived calls for the involvement of the faith in political projects aiming to lift the poor out of their predicament, delivering progress and development to the masses of the unfortunate. Indeed, reversing its previous position, itself based on the modernisation thesis that sought to disentangle the market from the sacred, the World Bank has more recently adopted a more 'inclusive' approach. Propelled by the writings of its former president - James Wolfensohn (2011) - and a former director - Robert Calderisi (2013)- it now encourages more faith-based NGOs to get involved in development efforts, acknowledging the positive role that 'spiritual' issues play in achieving 'holistic human development'. For Erica Bornstein, however, the link between the metaphysical and the pragmatic has never been severed for it has always been the case that religious beliefs 'inform the way development is planned, conceptualised, motivated and instituted' as well as 'received, interpreted, and accepted in specific social and historical contexts' (2003: 2; Browne 2009).

The special volume sets out to explore the complexities arising from contemporary intersections of religion and the economy as the later apply to public projects of transferring value to the poor for the purpose of alleviating their suffering, and improving their condition. Such exploration is carried out within the delimited horizon of the societies and cultures which convention has grouped together in the region of Southeast Asia. The volume aims at providing evidence of the new significance that religious interventions in the field of poverty alleviation are assuming in that part of the world in the era of neoliberal reform. Two particular events, the Asian financial crisis of the late 1990s and the Asian tsunami of 2004, have heightened awareness of the masses of people vulnerable to poverty and natural disasters, and the role that international and national bodies can play in protecting households from sudden losses of property, employment and income, as well as from contingencies such as ill-health, ageing, volcanic eruptions, and earthquakes. The case studies presented in this volume draw upon ethnographic materials from the mainland and the islands, from Vietnam, Cambodia and Thailand in the north, to Malaysia and Indonesia in the south. They all provide ample evidence of the new roles that faith-based organisations and movements have increasingly assumed in safeguarding human welfare in the midst of historical conditions characterised by an acute shortage of employment opportunities, precarious economic arrangements, and unexpected disruptions in sourcing livelihood. Needless to say, such conditions continue to characterise life for the lowest strata of the peoples of this region despite, or possibly because of, their countries' more recent return to economic growth.

Each of the papers is concerned with the relation between religion- be that Islam, Christianity, or Buddhism - and poverty both with respect to understanding the morality underpinning the impulse to lift others out of poverty, and the kinds of interventions that religious notions and ideas give rise to in contemporary times. More particularly, the papers 
deal directly with the ways in which 'traditional' forms of religiously inspired interventions into the lives of the poor are currently been reformed and recast as a response to new forms of governmentality, themselves marked by the introduction of neo-liberal regimes of value into Southeast Asian societies. At the same time, the papers look into the manner in which the world religions dominating Southeast Asia are been revamped and transformed both by global religious currents such as Christian evangelism and the Islamic reform movement, as well as by various domestic political forces such as the Red Shirt movement in Thailand, the renovation (đổi mó́i) policies in Vietnam, and on-going calls for reformasi in Indonesia (Hefner 2010). In this very volatile context, new forms of poverty are recognised and constituted, new sets of arrangements between the haves and the have-nots are instituted, and new tools for life's improvement are devised and deployed. The volume charts recent developments in the field of religious value transfers by means of providing rich ethnographic case studies that address theoretical and regional concerns with poverty, the values that motivate religious efforts for poverty alleviation, and the politics at play in the management of poverty.

Across the spectrum, religious charity is explicitly undertaken with the aim of not only helping the poor and the destitute, but also for bringing about certain benefits to donors. As several scholars have noted, to the extent that charitable acts are held to generate merit and ensure better chances of salvation for donors, faith-based generosity by-passes the distinction between altruism and individual interest. In line with studies from other parts of the world (Bornstein, 2003; Muehlebach 2013; Scherz 2014; Malkki 2015), the approach we adopt here is to regard such religiously inspired activities as socially efficacious techniques geared towards fashioning and shaping the self and the other, the donor and the recipient, in a highly specific manner. In this respect, we take activities of religious value transfer to amount to devices essential and instruments necessary for the formation and reformation of the subjectivities of all those involved. At the same time, we labour to explore the links between the active cultivation of the requisite religious sensibilities and dispositions, on the one hand, and the demands neoliberal programmes of polity restructuring and assumptions about wealth generation place on the peoples of Southeast Asia for their successful participation in a globalised world, on the other.

The effects religious value transfers have on the subjectivities of those involved are provisional and insecure. It is precisely for this reason that increasing demands are made for routines to be repeated with great regularity, and for vigilance against sin and demerit to be constant, even when outward behaviour complies with religious stipulations. The range of effects this volume brings to light are, however, neither uniform nor unchanging. Instead, they vary from one context to the next for they are shaped by particular historical and social realities. The conduct of religious value transfers are advantageous for assuaging the political anxieties of the middle-classes in Thailand, give new meaning to the lives of development professionals in Cambodia, improve the quality of human resources in Malaysia, manage widespread risks and uncertainties in Vietnam, and hasten the arrival of a prosperous future in Indonesia.

As well as conceiving value transfers as ritual performances, the undertaking of which brings about certain effects in one's relation to one's self as well as in one's relation to others, the volume also attests to the incessant, complex and undetermined entanglements the faithful 
establish through practices of giving between this life and the next. By answering both to distinct metaphysical injunctions for salvation in the hereafter, and to pressing social concerns regarding welfare in the here-and-now, the practice of value transfers is crucial in establishing a strong connection between one's current and posthumous existence. This connection finds recognition in ideas regarding the operation of alternative and intangible 'currencies' different religious traditions entertain, albeit with considerable variation, which redemption upon death facilitates the atonement of sins committed in this life. One of the aims of the introduction is to elaborate the significance of such 'refined' currencies through a short comparative exercise of their place in Buddhism and Islam, the two religions that predominate in Southeast Asia. Before I do so, however, I have to set the context for the study of charity and the management of poverty in the region, and beyond.

\section{Poverty, Welfare, Governmentality}

It is widely acknowledged that in recent times, global concerns and policies relating to poverty revolve around the deployment of new sets of tools: community development, microcredit, empowerment, direct cash transfers, and social capital are considered valuable, cost-efficient means of helping the poor help themselves in realising their potential (Goenka \& Henley 2010; Ferguson 2015). Since the publication of the 1990 World Development Report by the World Bank, the centre of gravity has 'shifted from the problem of what the poor lack to what the poor have' (Endo 2015: 5), and then back again to underlining privation.

Inspired by the work of Peruvian economist de Soto (2000), the first shift stimulated a discourse that placed a premium on the inventarisation of poor people's assets - homes, labour skills, kinship - for purposes of easing their access to (micro-) credit, while making them solely responsible for lifting themselves out of poverty, principally through hard work. As a result of this shift, the view of poverty once prevalent in policy circles - namely, poverty conceived as a social relation mediated by differential access to the products of labour, expressed by differential rates of social participation, and addressed through re-distribution (Townsend 1979) - became politically marginal. This was especially true in post-2008, austerity Europe where such approach reigned supreme for over half-century, crucial as it was in grounding the politics of welfare states. In its place an alternative framework arose, one that viewed poverty as a matter of inadequate/inappropriate utilisation of resources, often resulting from the imperfect matching of markets, raw materials, and technology with human skills and capacities. Such framework called upon the poor to achieve self-reliance through the ethics of entrepreneurship, involving the application of market values to all aspects of one's life, ranging from socialising to work and education (Elyachar 2005).

A variant of this new framework followed a slightly different path, however. By perceiving poverty in terms of capability deprivation, its advocates suggested that the poor are suffering from restricted prospects to achieve goals taken as universal for human welfare. 
'[T]o live in adequate housing, to avoid premature mortality and live a normal life span, to be well nourished, and to avoid ill-health and poor mental health' (Hick 2014: 313) were taken as norms the poor encounter difficulties with achieving, not simply because of lacking resources, but primarily because their capacity to aspire is, in the first place, weak and underdeveloped. By turning such capacity into a measure, Appadurai underscores the continuing importance of the privation thesis, arguing that

'the capacity to aspire is not evenly distributed in any society [as] the relatively rich and powerful invariably have a more fully developed capacity to aspire [for] they have a bigger stock of available experiences of the relationship of aspirations and outcomes, because they are in better position to explore and harvest diverse experiences of exploration and trial.' (2004: 68).

Whether it is the poor's assets or shortages contemporary discourses highlight, the onus remains squarely on the poor in addressing social liabilities and managing future risks. Both the social supply of credit and the provision of info-training characterising many empowerment regimes are carefully designed to intervene in social life so as to create and sustain entrepreneurially-minded individuals as the basic units of action. In Enguld's phrasing, 'while liberal cosmopolitans may disagree on the most important aspects of poverty, they are in no doubt about personal autonomy as both the means and end of alleviating poverty' (2012: 287).

The emphasis neoliberalism places on the personal autonomy and individual responsibility of the poor is of great importance - it marks a significant shift in the way poverty has historically been conceived and managed. Whereas in Europe, the poor had for centuries been physically excluded from society and driven away from the cities, the emergence of work-houses in the $16^{\text {th }}$ century England, and the Hopital Général in $17^{\text {th }}$ century France reflected the formation of new sensibilities and the assumption of duties of assistance, especially in times of economic crisis. 'For the first time', writes Foucault, 'purely negative measures of exclusion were replaced by measures of confinement' (1965: 48) with the poor, the insane and the unemployed being 'looked after' by a new set of institutions, themselves combining the functions of hospital, prison, and workshop. According to these new arrangements, confinement was closely associated with work as those who were out of work were confined, and work was henceforth given to those thereby confined.

This manner of managing the poor was transformed from the late $19^{\text {th }}$ century onwards. The politics of citizenship and recurrent economic and political crises ravaging the continent required that the sharp inequalities generated by capitalism were ameliorated by social rights becoming an inseparable part of life, especially in the post-World War II Europe. As Garland writes in his critical evaluation of the welfare state, as 'the economic depressions of the 1890s and the 1930s revealed, the economic hazards of industrial society rendered unworkable the older forms of social provision such as charity, churches, Poor Law, and the workhouse' (2014: 351). The management of poverty under the guidance of the welfare state must therefore be understood as resting on an unspoken agreement struck between the body of citizens and the body of capital. Such contract made capitalism more efficient and resistant 
to fundamental change by means of the social peace and the inclusiveness assured by the implementation of social protection and insurance schemes of near-universal currency (Berend 2005; Donzelot 1991).

In a series of lectures given at the beginning of the end of this political arrangement, Michael Foucault argues that from the $18^{\text {th }}$ century onwards, a new form of power was invented in Europe. This new form he refers to as governmentality, arguing that it has the population as its target, political economy as its major form of knowledge, and apparatuses of security as its essential technical instrument' (2009: 108). Governmentality which includes the welfare state, strives 'to improve the condition of the population, to increase of its wealth, its longevity, health' (2009: 105), and relies on the science of political economy to furnish it with all the necessary knowledge regarding its principal object. In particular, governmentality privileges the domain of the market as a sui generis and largely independent domain so as to supply the core values, appropriate rationales and effectual tools required for securing the welfare of the population. Foucault identified neoliberalism as the latest form governmentality has assumed, defining it as a political project aiming to extend the rationality of the market in terms of inventing new commodities and pursuing profit through competition, to all aspects of social life. He was also at great pains to show the ways in which neoliberalism in the late 1970s France was taking the welfare state apart, replacing it with a new regime of value whereby what was once considered a social right was fast becoming a commodity (2008: 185-213).

Foucault's work is important for my purposes for two reasons. First, by highlighting the intimate connection between the welfare of the population and the objectives of governmentality, he opens up the possibility of considering practices of care for others as intrinsically related with the exercise of power. This is a central paradox an increasing number of anthropological studies on charity and development are particularly good at showing ethnographically (Clark 2004; Gupta 2012). Second, by disentangling the analysis of power from the study of the state, Foucault conceived domination as diffused throughout the space of the social, and produced and reproduced through practices of subjectivation. In this regard, he postulated neoliberal governmentality as hinging on two inseparable elements: the production of subjectivities in the manner of homo economicus, and the earmarking of civil society as an expansive domain of application, writing that in an ideal situation,
'[h]omo economicus is, if you like, the abstract, ideal, purely economic point that inhabits this dense, full and complex reality of civil society. Or alternatively, civil society is the concrete ensemble within which these ideals points, economic men, must be placed so that they can be appropriately managed' (2008: 296).

Taking its cue from Foucault, the current volume is concerned with the ways in which the pairing of mass creation of entrepreneurial subjectivities and the promotion of associational life under the aegis of the concept of 'civil society', is currently played out in Southeast Asia, focusing its lens on faith-based non-governmental organisations and their activities in managing poor. As several influential writings on the processes under way for reforming philanthropic practices according to the dictates of universal democratic marketization make 
aptly clear (Green \& Bishop 2008; Nickel \& Eikenberry 2009), civil society can no longer be taken as either an innocuous counter-balance to the state or entirely separate from the market, free from considerations of profit and returns on investment.

In Southeast Asia, the post-1997 ascendancy of market-based techniques for attaining prosperity has meant neither the wholesale abandonment of the "developmental state" (Johnson 1999) nor has it led to the demise of state welfare. Though the state currently assumes less pivotal a role than it did in the 1970s when at the height of the developmentalist paradigm, it singlehandedly orchestrated the economic process through direct investment, while carrying out massive poverty reduction programmes, it nevertheless continues to be an indispensable actor in the new apparatus of power (Rudnyckyj \& Schwittay 2014). This is mainly due to its roles in regulating markets and commodities, ensuring an investmentfriendly legal environment, and commissioning lucrative infrastructure projects. Despite the fact that development, inclusive of poverty alleviation, 'is no longer state-led or state-centred, but rather financially driven and privately procured' (Carroll \& Jarvis 2014), Southeast Asian governments have sought to expand rather than contract state welfare programmes. This is especially so since the adverse consequences of the Asian financial crisis became politically prominent (Hort \& Kuhnle 2000; Croissant 2004). As Cook and Pincus (2014) argue, there have been significant efforts lately for social provisions in health, education, and social insurance to swell beyond the confines of the formal and the public sectors, and spread to those employed in agriculture and the informal sector. The programmes Thaksin Shinawatra put in place as Prime Minister in the 2000s in Thailand such as life insurance for the poor, scholarships for indigent students, and rural day care centres, and Joko Widodo launched in Indonesia in 2014 through Indonesia Health Card, Indonesia Smart Card, and Family Welfare Fund can't be easily dismissed as populist. Rather, they index the continuing importance of the duty of care leaders are expected to show to their followers, even in situations where the latter are expected to shed their dependency on state institutions. Moreover, this expansion of state welfare is closely correlated with macro-economic priorities: post-developmental states aim to boost the competitiveness of their labour market, ensuring that the workforce meets standards of health and levels of skills likely to attract foreign investors.

Over the past decades, international bodies have held Southeast Asian countries as a successful example of the poverty-reduction effects of economic growth and the improvements in average incomes achieved during the "developmental state" phase and after. Indonesia was applauded by the World Bank for reducing its official poverty rate from $60 \%$ in 1970 to $17 \%$ in 1987 (Cook and Pincus 2014: 4). In the post-1997 world, it was Vietnam with its transition to post-socialism that was celebrated as its poverty reduction efforts brought rates down from 25.4\% in 1996 to $8.9 \%$ in 2001 (Warr 2006: 285). During the same period, Malaysia was recorded as having virtually eradicated extreme poverty the World Bank measures in terms of personal income equal to or lower than $\$ 1.25$ a day. It is common knowledge however that such sharp reductions have been mainly achieved on the basis of very low and arbitrarily drawn official poverty lines. It is moreover difficult to compare relevant statistics because of major disparities in the technical details of surveys, measurements and calculations (Priebe 2014). In this context, it should be kept to mind that overall inequality, i.e. relative poverty is evidently growing, and becoming more visible a concern (Rigg 2003; Sumner, Suryahadi \& Thang 2012; Endo 2015). This trend which has region wide validity, is best summarised by Taylor who writing about Vietnam notes that 
'The poverty reduction focus and its successes [... are] revealing for, during a period in which the number of people living below the poverty line did indeed shrink, the gap between rich and poor yawned ever wider. [...] The goal of raising people above a poverty line [...] tells us little that is meaningful about equality or social mobility. [...] Interventions to reduce poverty do not address the social relationships that tie the relative losses of the poor to the gains of the rich' (2004: 24-25).

An additional pattern relates to a large share of the population living around the poverty line. These are people who are very sensitive to slight changes in their mode of livelihood and the overall economy. As a result, they can find themselves living below whatever standard has been officially adopted quite easily and abruptly (Ananta \& Barichello 2012; High 2009). In this regard, Endo's (2015) study of vulnerability and uncertainty amongst Bangkok's informal workers carries significance beyond Thailand's immediate context when he remarks that

'Members of the urban lower class face precarious housing and work situations, and frequently choose jobs or places to live on the basis of life circumstances. [...] Thailand's social security arrangements are not geared to deal with the urban lower class, as the majority of such individuals are not stably employed but, rather, work as unskilled labour or within the informal economy. [...] Their current living conditions remain vulnerable to fires, layoffs, evictions, and other threats' (2015: 1-2).

\section{Charity, Religion, Subjectivity}

With few exceptions (Scott 1987), anthropologists working on Southeast Asia have paid little systematic attention to value transfers such as alms and other donations, as an object of sustained ethnographic inquiry in its own right. And yet, ethnographies, both classic and more recent ones, are replete with information about Buddhist merit making activities involving donations, and the practices of generosity that permeate Muslims' lives, especially during the month of Ramadan. When the consideration of value transfers is not subsumed in debates regarding the degree to which local religions are syncretic or not - as is the case in the dispute between Geertz (1960) and Woodward (1988) regarding Javanese ritual meals they are basically treated as part of wider patterns of reciprocity. This is especially true of Tambiah's $(1968,1970)$ classic studies of Thailand which show how the merit alms generate is a return Buddhist monks make for the offerings they receive, with other merit making activities, such as ordinations and funerals, being part of kinship performances. 
The relative neglect of exploring value transfers in their own right however is beginning to be addressed (Joll 2012). A new generation of scholars is keen to view charitable donations as central rather than incidental to academic concerns regarding the ways in which the religious articulates with the economic, and explore the manner in which poverty as an on-going political concern is intimately connected to practices of giving. This is a perspective and endeavour the current volume shares with an increasing number of anthropological studies on Islamic charitable practices world-wide (Atia 2013; Mittermaier 2014), which starting point is the recognition that almsgiving corresponds to a form of 'financial worship' (Benthall 1999). It is also a standpoint pertinent to an evolving body of scholarship that places gifting at the centre of understanding the ways in which internal, class relations and external, international hierarchies are perceived and played out in the Buddhist Southeast Asia (Bowie 1998; Chaisinthop 2014; High 2010). Such research highlights the ambiguities marking value transfers with gifting manifesting normative behaviours such as generosity, selflessness and civic duty, and yet remaining haunted by suspicion, antagonism and conflict, stressing the dynamic co-constitution of value transfers, and giving due recognition to the contributions both sides make to the accomplishment of exchange (Bowie 1998).

Such expanding body of work has profited from historical scholarship and other anthropological work, drawing in particular on studies of religious subjectivities. With respect to the former, transformations in practices of religious charity whether Buddhist or Islamic is becoming more of a direct concern for historians of Southeast Asia with Ingleson (2012), Nguyen-Marshall (2008) and Fauzia (2013) joining forces with historically inclined social scientists (Brown 2008, 2014; Retsikas 2014, 2015; Schrawers 2001, 2011). In question is not only the ways in which the advent of modernity changed the manner in which value was recognised and transferred, especially with regards to matters of institutionalisation, rationalisation and accountability (Fauzia 2013), but also the extent to which colonialism was predicated itself on the application in the colonies of charitable projects first conceived and executed in the metropolises with regards to managing their own population of paupers (Schrawers 2001, 2011). Historical research has thrown up additional challenges to common sense understandings of charity. For example, Brown (2008) has persuasively argued that Islamic endowment funds in the $19^{\text {th }}$ and $20^{\text {th }}$ century Singapore aimed as much at providing social welfare to the poor as serving entrepreneurial purposes, acting as mechanisms for the accumulation of assets, thus aiding the perpetuation of commercial relations that tied the diasporic community of elite Hadhramis together.

Brown's (2008) characterisation of such practices as 'ethical capitalism' both advances and echoes a wider body of work on the intersections of capitalism and religion. Such work pays particular attention to the making of religious subjectivities to meet the demands of neoliberal era. In this regard, Max Weber's (1985) framework of elective affinity between capitalist accumulation and Protestant asceticism has been put to use by researchers working in Southeast Asia to argue that recent currents of reform found both in Islam and Buddhism, may work synergistically with contemporary forms of economic value. In particular, work by Jackson (1999a, 1999b) and Kitiarsa (2010) on the reconfiguration of popular Buddhism in Thailand due to influences exercised by the on-going commodification of social life carry unmistakable parallels with research findings from Malaysia and Indonesia. Sloane (1999), Feillard (2004) and Rudnyckyj (2010) show that Muslim 
reformers' stress on personal transformation, self-discipline, individual accountability to God both inform and are informed by entrepreneurial attitudes largely congruent with the demands of post-Fordist production. The emerging picture is quite clear: religious subjectivities across the region are reconfigured along the lines of neoliberal priorities, and material wealth is acquiring religious value that was previously lacking. Though the austerity characterising Weber's $16^{\text {th }}$ century Protestants, along with the formidable urgency for the practice of salvific semiotics, seem absent amongst the Buddhists and Muslims, there is nevertheless a certain process of sacralisation of monetary prosperity under way that warrants comparative attention.

In the chapters that follow value transfers are approached as twice inflected: biopolitical population control and the neoliberal wealth management articulate closely with each other in the fabrication of contemporary charity practice. This is a case whereby the value of charity is doubled: due to charity's positioning at the juncture of two distinct forces those dealing with the conduct of the population and those regulating wealth's production and distribution- value transfers obtain extra, surplus significance. This process is best exemplified in Chaisinthop's contribution in this volume: it looks at the political implications of domestic volunteer tourism in Thailand whereby affluent inhabitants of Bangkok venture to remote areas in the countryside, especially of the northeast, so as to do 'good'. The forms 'goodness' takes involves assisting NGOs with the delivery and implementation of education, development and conservation projects. Chainsinthop argues that voluntary trips involving are congruent with global market forces requiring that the state takes a backseat in welfare provision. At the same time they are integral to a particular mode of governance permeated by Buddhist ethics and concerned with upholding the rule of the 'good people' (khon di), offering unique opportunities for the cultivation of precisely the kinds of people required to carry such political project out. Voluntourist trips are occasions whereby members of the metropolitan middle-class encounter their social others in contexts marked by profound asymmetries, providing the training ground for the acquisition and display of dispositions such as generosity and kindness. The fact that such dispositions are widely recognised as the hallmark of morally and politically superior persons makes voluntourism of central importance in contemporary Thai politics, especially those espoused by the 'yellow shirt' movement advocating for elite rule over the masses as the latter are unprepared to participate in democratic politics because of their assumed moral inferiority and corrupt nature.

Chainsinthop's invitation to describe value transfers in terms of hierarchy and asymmetry is taken up by Marouda in her article on Vietnam. Marouda's starting point is that value transfers involve traffic not only amongst humans, but also between humans and nonhumans. The latter involve the ghosts of those unfortunate enough to have died in violent circumstances and/or those not cared for by kin and kith, conceived as a mass of destitute and hungry souls, roaming city streets and market places, looking for food, drink and other necessities. Rather than portraying them as the passive beneficiaries of human bigheartedness, Marouda stresses the influence they exercise on the affairs of the living. In this regard, she centres her account on the menace ghosts can unleash if left unattended to, and the opportunities for prosperity they present strangers with if catered to with generosity. The point she makes is vital: Vietnamese ghosts should not be restricted to the inactive end of charity for they index a force capable of eliciting gifts and inducing offerings. The means by which this is accomplished involves the making of threats to livelihood and entails promises 
of handsome rewards. It is no coincidence then many Vietnamese traders and shopkeepers often stage rituals for the benefit of ghosts roaming nearby spaces: the expectation of reducing risks inherent to commercial endeavours, and multiplying prospects for business success is always present.

The themes of risk and reward are further elaborated in Fechter's study of Western aid professionals in Cambodia who, in addition to their paid jobs, engage in voluntary activities, offering their services, skills and expertise to locals for free. Wondering about how best to understand such excess of goodness, Fechter considers such cases to be both the result of the alienation mid-level expatriate workers experience in the workplace, and an extension of their life vision. In particular, she argues that their engagement in charity is partly a reaction against the overly bureaucratic, top-down nature of work performed by development agencies. At the same time, it is in continuity with what brought such people to the aid sector in the first place: the 'desire to help others' remains their true vocation. Given that the majority of aid professionals working in Cambodia head from Australia, Western Europe and the United States, that is, societies where Reformed Christianity has been deeply embraced, the concept of 'vocation' assumes particular importance as it brings such practices well within the salvific horizons of a faith that equates labour with worship. Indeed, Weber (1985) was at pains to show that for Martin Luther, it was the duty of each and every reformed Christian to submit to God's will through taking up a vocation: as such, a vocation is no better or worse than another for it amounts to God's plan for each and every individual.

Retsikas' contribution builds on the recognition that development interventions for the uplift of the poor and religious metaphysics concerning salvation share much common ground. This ground is constituted by a temporal orientation privileging the future at the expense of the present and the past, envisaging times-to-come as improved versions of timespresent and times-past (Retsikas 2015). In this regard, his paper is concerned with the manner in which a particular Islamic charitable organisation in Indonesia conducts much of the everyday activities of its employees and those of its poor beneficiaries so as to make time pass, hastening the arrival of the future. A key dimension of the time work accomplished relates to the institutionalisation of motivational sessions commonly undertaken with the aim of unlocking the potential thought to inhere in the future and to subsist within human subjects. Such unlocking is conceived as necessary for improving personal and social welfare, itself understood in the double sense of economic success and religious virtue. The standards and values this charitable organisation supports enjoy wider currency in $21^{\text {st }}$ century Indonesia and find political expression in the movement advocating for an ekonomi Islam, itself involving the supply of easily accessible syariah-compliant credit, and the creation of the next generation of pious entrepreneurs.

The final contribution is by Schulz whose work focuses on Christianity in East Malaysia and its role in apprehending and realising the potential value of the poor as mass following and cheap labour force. Schulz's ethnography relates to two schools run by South Korean charismatic missionaries that cater to the needs of children of illegal migrant workers who arrive in Sabah mainly from Indonesia but also from the Philippines, in search of employment. Despite the church's obvious concern for the well-being of the children concerned who are otherwise excluded from state education provision, and its message of equality and salvation for all, it is still the case that Christian charitable engagements with 
poor migrants work to ensure the docility and acceptance of the discrimination they face. Though churches in Sabah generally claim to empower young non-Malaysians through education, they inadvertently work to reproduce the latter's social subordination and guarantee their marginality. Schulz's conclusion is all the more surprizing given the tensions that normally exist between Christian churches and the Malaysian state which is often keen to act as the main advocate for the rights and privileges of Islam and Muslims in the country.

\section{Salvation, Credit, Uncertainty}

Studies of value transfers' contemporary significance would however remain incomplete if they only attend to the double inflection of charity by the dictates of modern governmentality. As noted above, the volume gives due recognition to concerns over population and wealth production and distribution that shape the place and relevance of charity in our times. Yet to limit our understanding of value transfers to such approach amounts to conceiving value as determined by the presuppositions informing the practice of political economy, both classic and current, whether liberal, neo-liberal or Marxist. The main problem with such agenda is that it posits the value of value transfers as hinging on the latter's accomplishments for furthering the goals of governmentality: as such, it affirms rather than destabilises the primacy of political economy in ascertaining significance and assessing worth. If there is criticism to be levelled against Foucault's later studies, it could only point to the relative absence of a theoretical framework robust and detailed enough so as to render political economy secondary to, and therefore derivative of, priorities of an altogether different order. For instance, on account of conceiving the economic in a manner totally alien to the market, either historically or culturally, such order would amount to a reconfiguration of government as its main target would be other than population as a demographic aggregate. Alternatively, by tying political economy to a very different set of instruments and techniques of rule, such order would conceive of monetary wealth as subordinate to well-being, itself defined in terms of radically unfamiliar standards and measures. It is indeed the case that a lot of scholarly attention has been directed to historical and ethnographic evidence attesting to the recent invention and far from universal practice of market cultures. And yet, with few notable exceptions (Agamben 2011) such attention has led neither to a radical reconceptualization of power nor to a fundamental reimagining of the economic. For the most part, such scholarship has been concerned with times prior to, and peoples assumed as barely touched by, capitalism. The question therefore remains: is there currently a force in operation that portrays itself as primary in securing well-being, reserving for the market a subservient role in the promotion of its own standards? If indeed there is, how does it manifest itself ethnographically, and by what means does it 'encompass' the market? Another way of phrasing such inquiry is ask about the limits processes of commodification come up against as it is precisely at the spaces defined by impasse and deadlock that capitalism, encountering challenges to its expansion, might reveal something more about its nature than usually 
assumed. The challenges to be mapped are indicative of the presence of a force that capitalism can't fully domesticate, and bespeak of processes of ordering life otherwise.

While the commodification of living has been unrelenting over the last two centuries with new articles fabricated and marketed with every new turn of technological innovation and specialist intervention in fields as diverse as fertility, knowledge and the environment, the mortal character of existence remains a drama the market has yet to devise adequate solutions for. While life itself can be inaugurated, improved and prolonged with the deployment of instruments and techniques made available by means of capitalism's on-going search for new vistas for profit generation, death itself as a destiny facing all living creatures, inclusive of humans, remains unaffected by capitalism's expansive, triumphant march. True, the processes surrounding death and death's implications for the living have been duly arrested by commodity exchange. The means of such capture include pensions for old age, the provision of medical care, the conduct of funeral processions and inheritance rights. Nevertheless, the desire for life eternal has no recourse of becoming fulfilled, in the foreseeable future at least, by the possibilities afforded by commodification. Death and its corollary, the desire for life unlimited, occupies the very limit contemporary forms of governmentality can neither fully satisfy nor completely arrest. At the same time, the market can neither evade nor surpass the inescapability of death. ${ }^{1}$ It is precisely at this point that capitalism reaches an impasse and political economy assumes secondary importance, becoming subject to a force promising to deliver what the market can't do. This promissory force, conventionally labelled as religion, involves the making possible of life eternal.

To adherents of many religions, death is not the end of life but a break, an interruption itself marking the beginning of an altogether different life. In addition, for faiths whereby salvation is not sought on the basis of doctrines of predestination (see Weber 1985), between this life and the next life, a thread is assumed to actively persist. This is so for the activities undertaken during one's lifetime carry unmistakable consequences regarding the possibilities opened up by death. The thread linking this life with the next places great emphasis for the attainment of salvation in the hereafter on value transfers: the latter are attributed the capacity of directly affecting, and openly influencing one's posthumous existence. In this regard, Parry has insightfully observed that

'An elaborated ideology of 'pure' gift is most likely to develop in state societies with an advanced division of labour and a significant commercial sector. But what is also in my view essential to [gift's] articulation is a specific type of belief system, as is suggested by the fact that in all of the major world religions great stress is laid on the merit of gifts and alms, ideally given in secrecy and without expectation of any world return (1986: 467).

\footnotetext{
${ }^{1}$ Strathern (2012) notes that international conventions prohibiting human organs from been marketed, present (another) limit to commodification. As with death, organ donation is 'haunted' by money, especially as organ procurement and transplant services are underpinned by commercial interests. Yet, when compared to death, the limit organ transfers institute is very different: such limit is a human creation and subject to human control. Moreover it is represents a relative rather than absolute limit for it is amenable to (legislative) change.
} 
When situated within salvific contexts, the value of value transfers changes radically: it no longer derives from the service they perform to political economy but rests on the contributions they make to the likelihood of securing salvation. For making gifts, giving alms, and transferring value in general, adherents of all major world religions are rewarded in the salvific currency of merit, known as bun in Thai (Buddhism, from puñña in Pali), and pahala in Malay (Islam, sawāb in Arabic) (Joll 2010: 192-194). This alternative currency allows for the conversion of monetary wealth generated and accumulated through market transactions into posthumous well-being. This is the case whereby rich benefactors dedicate part of their wealth to the building of temples/mosques and orphanages with a view to securing a better rebirth, if they are Buddhists, or a place in Paradise, if Muslims. However, this does not mean that a better rebirth is a commodity that can be bought or sold on account of capital expended: the direction of encompassment is actually the reverse as salvation has no price, it is itself priceless. Strict conditions are placed upon value transfers to ensure this to be the case with both Islam and Buddhism stressing the importance of intention when undertaking such activity. In Islam, for giving to generate pahala, the right niyat (intent) is paramount: it should come straight from the heart and sincerely meant for Allah's glorification. In Buddhism, the primary aim is finding relief from earthly suffering through achieving control over desire. As Cook observes, 'it is impossible to transcend the cycle of rebirth, through the act of giving or receiving alms if the very act itself ensnares one further into the morass' of desire (2010: 142). Such is the paradox of salvation that if value is transferred with the expectation of self-aggrandisement, giving is without effect in generating merit.

The currency of merit comes into force immediately upon death: it express the value accumulated for the good deeds performed in this life, while making possible for the atonement of sins. ${ }^{2}$ In this regard, bun and pahala are units for measuring and storing value as well as means of accounting for the credit and debts the faithful have amassed during their lifetime. In the case of Buddhism, the mechanism converting bun into afterlife chances assumes an automatism guaranteed by the law of karma. As is well known, popular Buddhism in Southeast Asia does not narrowly revolve around world renunciation and the achievement of nirvana, but focuses on the attainment of a more satisfying re-birth. What karma postulates is that a relative reduction in suffering can be achieved through undertaking meritorious actions, and avoiding actions that earn demerit. As Tannenbaum puts it, 'karma is the investable consequence of actions: good deeds return good in this and other lives and bad deeds, bad' (1997: 192). In contrast, Islam relies for the mediated delivery of judgement on a God creator acting as sovereign: non-submission to divine Will amounts to an insult that requires the meeting out of punishment; conversely, sincere compliance earns Godly favour. The faithful are expected to account for their actions immediately after death, when two angels - Munkar and Nakir - put a series of questions to the deceased, passing provisional judgement. The second, and most important ruling, is deferred till the Day of Judgment,

\footnotetext{
${ }^{2}$ For the way the alms calculus works in Buddhism see Spiro (1970) and Keyes (1983); for Islam, see Joll (2012); the economy of merit is also true for Christianity, see Garrison (1994) and Coleman (2004).
} 
when Allah is to make His final decision as to who will enter Jannah (paradise) and who will be sentenced to Jahannam (hell).

Apparent differences between Buddhism and Islam as to the respective soteriological apparatuses are accompanied by marked divergences as to the devices in charge of converting value transfers into merit. In both cases, giving corresponds to one amongst several methods for earning credits, alongside the observing of virtue and the practising of meditation for Buddhists, and the observance of God's law and the reciting of the Quran for Muslims, for example. However, studies of Buddhism in Southeast Asia have generally defined merit making as principally involving the giving of alms to monks and of donations to temples. This is so for Theravada teachings suggest that the efficacy of the gift in generating merit partly depends on the worthiness of the recipient with the Buddha and the monks being most worthy due to their elevated rank (Tambiah 1968; Cook 2010; for further discussion see Bowie 1998). In Islam, the emphasis placed on religious figures and institutions of learning as potential recipients is shared with the prevalence of giving to the poor, especially to orphans and widows. However, in Islam such figures are not merely construed as recipients of charity; instead they recognised as entitled to a portion of the wealth commanded by the affluent (Retsikas 2014). For the latter, the payment of zakat corresponds to an obligation, thus amounting to a value transfer that circumvents the category of the gift. In this instance, the transfer of zakat earns merit both for wealthy who honour the obligation, those who collect zakat and those who are entitled to it.

In addition to merit being a medium of value that conjoins a person's this-world life to his/her after-life, it also functions as an object of exchange, becoming itself an article of transfer between distinct persons, primarily the living and dead. Despite their many differences, both Buddhism and Islam insist on each and every devotee being individually accountable for his/her actions. Yet, despite the fact that actions are single authored and sins are not subject to sharing, the merit the undertaking of virtuous deeds generates can be dedicated to the benefit of social others, influencing their prospects for salvation. The transference of karmic merit is a standard feature of many Buddhist rituals, inclusive of ordinations and funerals, which often conclude with the dedication of the merit generated to ones' parents and dead ancestors (Keyes 1983; Tambiah 1968). Bun is transferred with the explicit aim of improving the condition of the dedicatees, assisting them with attaining a better rebirth. In Muslim Indonesia, rites of commemoration include efforts towards influencing the posthumous condition of ancestors through making merit: instead of claiming ownership, those attending reassign it to the dead (Bowen 1993; Telle 2000). Though there are sharp disagreements between traditionalists and modernists regarding who can generate merit for whom, there is wide acknowledgment of the maxim that salvation is an open-ended process that is not restricted solely to one's own actions but others can contribute to it as well on account of (self-) sacrifice.

Friends in Indonesia repeatedly stress that Muslims hold two different accounts: one in the bank, the other with Allah. In the former, value is expressed in rupiah, in the latter, in pahala. While it is certainly the case that rupiah are not exchangeable for a place in Paradise, monetary wealth can be dedicated to the promotion of good, and the elimination of evil, as defined in syariah, activities which earn one posthumous credit. The crux of the matter is that unlike the bank balance, nobody knows how much one has in store in merit: the 
amount of pahala accumulated by each and every faithful is a mystery to all but Allah, with the balance awaiting inspection on Judgement Day. The element of uncertainty is therefore fundamental in the salvific economy of merit: while worldly currency is varied and its amount is known for it is computable, the currency of merit is universal, yet corresponds to a puzzle for it bypasses human enumeration and defers computation.

Uncertainty is compounded by two further concerns: first, merit is lost to sin; inadequate faith, incorrect actions, improper feelings incur debits, and further reducing one's overall account balance. Second, the injunction for generosity to be conducted in the manner of sacrifice, i.e. without regard for a return, is in direct tension with the existential pursuit of salvation through the individual accumulation of merit. Therein rises a paradox and an impasse: given the stakes involved, questions about how to practically navigate such impossibility are of immediate importance. Because all cases of giving that involve the expectation of a return are setoriologically compromised, intense feelings of self-doubt as to the intentions informing one's own actions go hand in hand with widespread suspicions regarding the motives behind other peoples' generosity. In the country I know best, Indonesia, the latter are perhaps more often raised in public than the former; yet, everyone quickly concedes that none can be sure about what lies in other people's hearts. This epistemic stance I take as equally important to anthropological endeavours. In its light, I suggest is that if uncertainty, impasse and impossibility characterise value transfers as understood from within a salvific perspective, this is primarily due to their capacity to index the inescapability and unpredictability of death and of what comes after its arrival. In this regard, the value of value transfers is neither wholly nor simply defined by the priorities and concerns of modern govermentality as to the welfare of the population and the pursuit of profit. Instead, the excess value of value transfers derives from the metaphysics of death and the openings death creates in terms of potential after-lives. The alternative economy of merit major world religions put in place by means of speculative efforts as to distinct ways of attaining well-

being in life unending, make death and its aftermath central to ascertaining the significance of living.

\section{Acknowledgments}

Special thanks to Maria Korasidou for introducing me, a long time ago, to the work of M. Foucault.

\section{References}

Agamben, Giogrio (2011), The Kingdom and the Glory, Stanford University Press, Stanford.

Ananta, Aris \& Richard Barichello (2012), Poverty and Global Recession in Southeast Asia, ISEAS, Singapore. 
Appadurai, Arjun 2004, 'The capacity to aspire: culture and the terms of recognition', in Rao, Vijayendra, and Walton, Michael, eds, Culture and Public Action, Stanford University Press, Palo Alto, pp 59-84.

Atia, Mona (2013), Building a House in Heaven, University of Minnesota Press, Minneapolis.

Benthall, Jonathan (1999), 'Financial worship: the Quranic injunction to almsgiving, Journal of the Royal Anthropological Institute (N.S.) Vol 5, No 1, pp 27-42.

Berend, Ivan (2005), Foucault and the Welfare State, European Review Vol 13, No 4, pp 551-556.

Bornstein, Erica (2003), The Spirit of Development, Routledge, London.

Bowen, John (1993), Muslims through Discourse, Princeton University Press, Princeton.

Bowie, Katherine (1998), 'The alchemy of charity: of class and Buddhism in Northern Thailand', American Anthropologist Vol 100, No 2, pp 469-481.

Brown, Rajeswary (2008), 'Islamic endowments and the land economy in Singapore: the genesis of an ethical capitalism 1830-2007', South East Asia Research Vol 16, No 3, pp 343-403.

Brown, Rajeswary (2014), Islam in Modern Thailand, Routledge, London.

Browne, Katherine (2009), 'Economics and morality: introduction', in Browne, Katherine E. and Milgram, Lynne Economics and Morality, Rowman \& Littlefield, Lanham, pp $1-40$.

Calderisi, Robert (2013), Earthly Mission, Yale University Press, New Haven.

Carroll T and Jarvis D S L (2014). Introduction: Financialisation and Development in Asia under late Capitalism. Asian Studies Review 38 (4), 533-543.

Chaisinthop, Nattaka (2014), 'Volunteering, dana, and the cultivation of 'good people' in Thailand', Anthropological Forum Vol 24, No 4, pp 396-411.

Clark, Janine (2004), Islam, Charity, and Activism, Indiana University Press, Bloomington.

Croissant, Aurel (2004), 'Changing welfare regimes in East and Southeast Asia: crisis, change, and challenge', Social Policy and Administration Vol 38, No 5, pp 504-524.

Cook, Joanna (2010), Meditation in Modern Buddhism, Cambridge University Press, Cambridge.

Cook, Sarah \& Jonathan Pincus (2014), 'Poverty, inequality and social protection in Southeast Asia', Journal of Southeast Asian Economies Vol 31, No 1, pp 1-17.

Coleman, Simon (2004), 'The charismatic gift', Journal of the Royal Anthropological Institute Vol 10, pp 421-442. 
de Soto, Hernando (2000), The Mystery of Capital, Basic Books: New York.

Donzelot, Jacques (1991), 'The mobilization of society', in Burchell, Graham, Gordon, Colin and Miller, Peter, eds, The Foucault Effect, University of Chicago Press, Chicago, pp 169-180.

Elyachar, Julia (2005), Markets of Dispossession, Duke University Press, Durham.

Endo, Tanaki (2015), Living with Risk, National University of Singapore Press, Singapore.

Enguld, Harry (2012), 'Poverty', in Fassin, Didier, ed, A Companion to Moral Anthropology, John Wiley \& Sons, Malden, pp 283-301.

Fauzia, Amelia (2013), Faith and the State, Brill, Leiden.

Feillard, Gwenaël (2004), 'Insuffler l'esprit du capitalisme à l' umma: la formation d'une ‘éthique Islamique du travail en Indonesie', Critique Internationale Vol 25, pp 93-116.

Ferguson, James (2015), Give Man a Fish, Duke University Press, Durham.

Foucault, Michel (1965), Madness and Civilisation, Pantheon Books, New York.

Foucault, Michel (2008), The Birth of Biopolitics, Palgrave Macmillan, Hampshire.

Foucault, Michel (2009), Security, Territory, Population, Palgrave Macmillan, Hampshire.

Garrison R (1993) Redemptive almsgiving in early Christianity. Journal for the Study of the New Testament Supplement Series vol. 77, Sheffield: JSOT.

Garland, David (2014), 'The welfare state: a fundamental dimension of modern government', European Journal of Sociology Vol 55, No 3, pp 327-364.

Geertz, Clifford (1960), The Religion of Java, University of Chicago Press, Chicago.

Goenka A and Henley D (eds.) (2010). Southeast Asia's Credit Revolution: From Moneylenders to Microfinance. London: Routledge.

Green, Micheal \& Matthew Bishop (2008), Philanthrocapitalism, Bloomsbury Press, London.

Gupta, Akhil (2012), Red Tape, Duke University Press, Durham.

Hefner, Robert (2010), 'Religions resurgence in contemporary Asia', The Journal of Asian Studies Vol 69, No 4, pp 1031-1047.

Hick, Rod (2014), 'Poverty as capability deprivation: conceptualising and measuring poverty in Contemporary Europe', European Journal of Sociology Vol 55 No 3, pp 295-323.

High, Holly (2009), 'The road to nowhere? Poverty and policy in the south of Laos', Focaal Vol 53, pp 75-88.

High, Holly (2010), 'Ethnographic exposures: motivations for donations in the south of Laos (and beyond)', American Ethnologist Vol 37, No 2, pp 308-322. 
Hort, Sven \& Stein Kuhnle (2000), 'The coming of East and South-East Asian welfare state', Journal of European Social Policy Vol 10, No 2, pp 162-184.

Jackson, Peter (1999a), 'The enchanting spirit of Thai capitalism: the cult of Luang Phor Khoon and the post-modernisation of Thai Buddhism', South East Asia Research Vol 7 , No 1, pp 5-60.

Jackson, Peter (1999b) 'Royal spirits, Chinese gods, and magic monks: Thailand's boomtime religions of prosperity', South East Asia Research Vol 7, No 3, pp 245-320.

Johnson, Chalmers (1999), 'The developmental state: odyssey of a concept', in WooCummings, Meredith, ed, The Developmental State, Cornell University Press, Ithaca, pp 32-60.

Joll, Christopher (2012), Muslim Merit-Making in Thailand's Far-South, Springer, Dordrecht.

Ingleson, John (2012), 'Fear of the kampung, fear of unrest: urban unemployment and colonial policy in 1930s Java', Modern Asian Studies Vol 46, No 6, pp 1633-1671.

Keyes, Charles (1983), 'Merit-transference in the karmic theory of popular Theravada Buddhism', in Keyes, Charles and Daniel, Valentine, eds, Karma: An Anthropological Inquiry, University of California Press, Berkeley, pp 261-286.

Kitiarsa, Pattana (2010), 'Toward a sociology of religious commodification', in Turner, Brian, ed, Sociology of Religion, Blackwell, Chichester, pp 563-583.

Malkki, Liisa (2015), The Need to Help, Duke University Press, Durham.

Mittermaier, Amira (2014), 'Beyond compassion: Islamic voluntarism in Egypt', American Ethnologist Vol 41, No 3, pp 518-531.

Muehlebach, Andrea (2013), 'The Catholicization of neoliberalism: on Love and welfare in Lombardy, Italy', American Anthropologist Vol 115, No 3, pp 452-465.

Nickel, Patricia \& Angela Eikenberry (2009), 'A critique of the discourse of marketized philanthropy in fast capitalism', American Behavioural Scientist Vol 52, No 7, pp 974-989.

Nguyen-Marshall, Van (2008), In Search of Moral Authority, Peter Lang, New York.

Parry, Jonathan (1986), 'The Gift, the Indian Gift and the 'Indian Gift", Man (N.S.) Vol 21, No 3, pp 453-473.

Priebe, Jan (2014), 'Official poverty measurement in Indonesia since 1984: a methodological review', Bulletin of Indonesian Economic Studies Vol 50, No 2, pp 185-205.

Retsikas, Konstantinos (2014), 'Reconceptualising zakat in Indonesia: worship, philanthropy and rights', Indonesia and the Malay World Vol 42, No 124, pp 337-357.

Retsikas, Konstantinos (2015), 'The promise: Islamic micro-finance and the synthesis of time', Deleuze Studies Vol 9, No 4, pp 475-502. 
Rigg, Jonathan (2003), Southeast Asia, Routledge, London.

Rudnyckyj, Daromir (2010), Spiritual Economies, Cornell University Press, Ithaca.

Rudnyckyj, Daromir \& Anke Schwittay (2014), 'Afterlives of Development', PoLAR Vol 37, No 1, pp 3-9.

Scherz, China (2014), Having People, Having Heart, University of Chicago Press, Chicago.

Schrawers, Albert (2001), "The "benevolent" colonies of Johannes can den Bosch: continuities in the administration of poverty in the Netherlands and Indonesia', Society for Comparative Studies of Society and History Vol 43, No 2, pp 298-328.

Schrawers, Albert (2011), 'A genealogy of corporate governmentality in the realm of the 'merchant-king': the Netherlands trading company and the management of the Dutch paupers', Economy and Society Vol 40, No 3, pp 373-398.

Scott, James (1987), 'Resistance without protest and without organisation: peasant opposition to Islamic zakat and the Christian tithe', Comparative Studies in Society and History Vol 29, No 3, pp 417-452.

Sloane, Patricia (1999), Islam, Modernity and Entrepreneurship among the Malays, St Martin's Press, New York.

Spiro, Milford (1970). Buddhism and Society, Harper \& Row, New York.

Strathern, Marilyn (2012), 'Gifts money cannot buy', Social Anthropology Vol 20, No 4, pp 397-410.

Sumner, Andy, Asep Suryahadi \& Nguyen Thang (2012), Poverty and Inequalities in MiddleIncome Southeast Asia, IDS, Brighton.

Tambiah, Stanley (1968), 'The ideology of merit and the social correlates of Buddhism in a Thai village', in Leach, Edmund, ed, Dialectics in Practical Religion, Cambridge University Press, Cambridge, pp 41-131.

Tambiah, Stanley (1970), Buddhism and Spirit Cults in Northeast Thailand, Cambridge University Press, Cambridge.

Tannenbaum, Nicola (1997), 'Blessing and merit transfer among lowland Shan of Northern Thailand', in Kammerer, Cornelia and Tannenbaum, Nicola, eds, Merit and Blessing in Mainland Southeast Asia in Comparative Perspective, Yale Southeast Asia Studies, Yale, pp 157-172.

Taylor, Philip (2004), 'Introduction: social inequality in a socialist state', in Taylor, Philip, ed, Social Inequality in Vietnam and the Challenges of Reform, Institute of Southeast Asian Studies, Singapore, pp 1-40.

Telle, Kari (2000), 'Feeding the dead: reformulating Sasak mortuary practices', Bijdragen tot de Taal-, Land-, en Volkenkunde Vol 156, No 4, pp 771-785. 
Townsend, Peter (1979), Poverty in the United Kingdom, Penguin, Middlesex.

Warr, Peter (2006), 'Poverty and growth in Southeast Asia', ASEAN Economic Bulletin Vol 23, No 3, pp 279-302.

Weber, Max (1985), The Protestant Ethic and the Spirit of Capitalism, Unwin, London.

Wolfensohn, James (2011), 'Foreword', in Haar, Gerrie ter, ed, Religion and Development (ed.), Hurst and Co, London.

Woodward, Mark (1988), 'The slametan: textual knowledge and ritual performance in Central Javanese Islam', History of Religions Vol 28, pp 54-89. 